\title{
ランタン，イットリウム，セリウム入り各タングステン 電極によるアーク特性の比較研究
}

一ガス・タングステン・アーク電極の研究(1)-

淞田福久**, 牛尾誠夫**, 熊谷详也***

Comparative Study on Fundamental Arc Characteristics

with La-, Y-, Ce-Oxide Tungsten Electrodes

-Study on GTA Cathode $(1)-$

by Fukuhisa Matsuda**, Masao Ushio**, Tatsuya Kumagai***

\begin{abstract}
A comparative study has been made of characteristics of gas-tungsten-arc (GTA) cathodes, consisting of tungsten mixed with a small quantity of lanthanum-, yttrium-, cerium-, thorium-, zirconuim- and magnesium-oxides respectively and pure tungsten. Arc starting performance, arc pressure, change in shape due to heavy loading are compared in DCEN polarity, and it is shown the superiority of La-oxide, Y-oxide and Ce-oxide electrodes in above characteristics.
\end{abstract}

Key Words: Tungsten, Tungsten oxide electrode, GTA welding, Refractory metal, Non-consumable electrode

\section{1. 緒論}

ティグ溶接やプラズマ浴接にもちいられる，いわゆ る,ガス・タングステン・アーク（GTA）では,タング ステン電極の形状や材䁈，および，その近傍のアーク電 流分布がアークの電気的特性や，陽極あるいは母材への 爇輸送特性などに強い影響を与える。

従来,このタングステン電極としては，酸化トリウ 么（トリア； $\mathrm{ThO}_{2} ）$ を数\%含有させたタングステンが 広く用いられてきた。てれは，タングステンにトリアを 添加することによって，電極からの熱電子放出特性を良 好にし、アーク放電電極としての性能の向上を図ったす のである。

しかしながら，近年，ロボット溶接に代表されるよう な溶接の自動化や, 高度に精密な溶接の要求が高まるに つれて，トリア入りタングステン電極の性能一とくに， 安定性や耐消耗性一では不十分になりつつあり，より優 れた性能を有する電極の開発が期待されている.

また，トリウム（Th）は放射性物䝯であり，その取り扱 いは法的規制をうける。 その管理のわずらわしさのた め, 国内でのトリア入りタングステン電極の生産は次第 に積極性を失いつつある。

とのような背景のもとに，著者らは，昭和 58 年末より 新しいタングステン電極の開発準備を始め, 眧和 60,61 年度の文部省科学研究補助金を得て, 種々の酸化物を添 加したタングステン電極を試作し，その特性を調査・検 討するととすに，さらに優れた性能をすつ新しい電極の 開発を目的として研究を進めている。本報告は, 現在ま での研究によってえられた，試作タングステン電極を対 象とした種々の実倹結果とその検討，および，得られた 新しい知見について述へる。

トリア入りタングステン電極の開発は真空管のフィラ

*原稿受付 昭和62年 5 月20日 昭和61年度春季全国大会で発表

**正. 具 大阪大学 Member, Osaka University

****学生員大服大学 Student Member, Osaka University
メント陰極としてのトリア入りタングステンの発明りか ら来るとされているが，アーク放電用陰極は真空管用電 子放出材料之比較すると次のような点でその使用状沅が 異なっている．すなわち，(1)アーク放電用電極は $10 \mathrm{eV}$ 程度の運動エネルギのイオン衝撃を受ける.(2)一般的に 大電流 (数 A一数 $\mathrm{kA}$ ), 大電流密度 $\left(10^{6} \sim 10^{8} \mathrm{~A} / \mathrm{m}\right)$ て 用いられる.(3)かなりの高温 $(2000 \mathrm{~K} \sim 3500 \mathrm{~K}$ ) になる. (4)酸化性需国気で用いられることあある。

トリア入りタングステン電極がアーク放電化初めて適 用され，その結果が公表されたのは1951年である2). 米 国 GE 社では，純タングステン電極をもちいたアークの 起動性および維持安定性を改善するためタングステンと トリアの潉合焼結電極を陚作しその性能を実 験 検討し た。添加されたトリアの量は1〜50\%であった，アーク の起動時の举動を筧察した結果15\%以上を混入して屯, ほとんよ゙結果に差牲じないこと，1\%ではトリアの弥 発消散力゙起こること，5\%程度の添加がその起動性改善 における效果を最む表わすとと，などが示されだ．

我が国におけるアーク放電用電極の研究は安藤，西川 等によるもの以外には殆どない，彼らはアーク放電中の 写真撮影を行ない, 乾板の黒化度から電極表面温度を推 定した5)。しかし，乙の测定では電極先端を㠅うアーク 光の影響はさけられない，とくにその影響を除去する工 夫はされておらず，乙の結果にたいする信頼度は低いと 考えられる。

\section{2. アーク放電用電極に要求される条件と 試作電極}

アーク放電を满成する要素は，電極 (物頯, 形状)，作 動ガス (組成, 封力), 幾何学的配置, 電源系であり, こ れら四種の要素が, アークプラズマの温度場, 流体場, 熱輸送に支配的なパラメー夕を決定する．特に，電極 は，電流の連続性を条件として，固体とプラズマ気体が 接する領域であり，プラズマの性筫に強く影響をあたえ る.ア一クの安定性は,アークの電極領域の物理的化学 的現象の安定性上, 電極およびその近傍のアーク電流が 


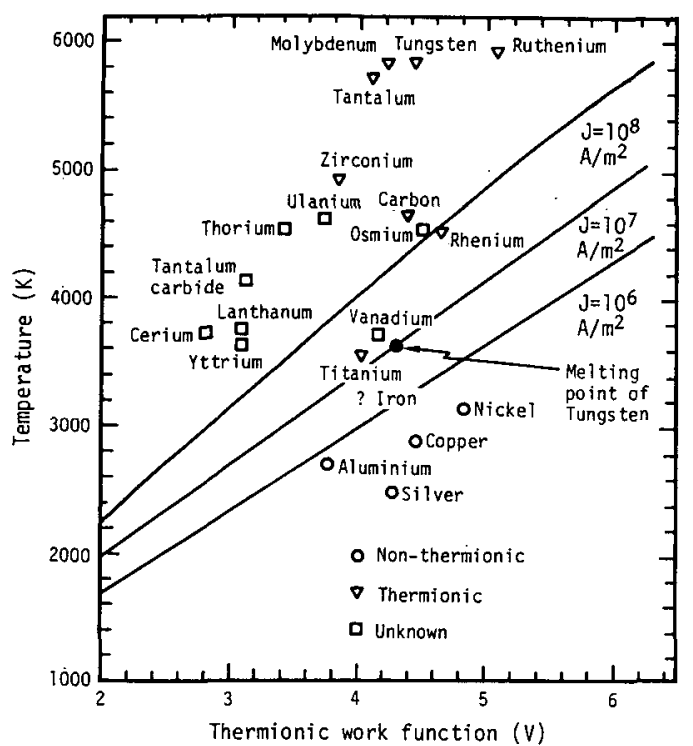

Fig. 1 Temperature for thermionic emission at various current density levels. Points show boiling point and work function of pure elments

誘起するプラズマ流が担っており，その電極領域の諸現 像には，電極物質の高温での挙動あるいは熱的状態が支 配的に影響する。したがって安定なアーク放電を維持す るためには，陰極として，比較的広範囲にわたって高温 定常状態を形成し，必要之されるだけの電子故出を行な うことのできる，いわゆる，熱陰極が用いられる。

一般に高温の状態におかれた物質からは電子が故出さ れ (熱電子放出)，アーク放電の熱陰極は漓温の状態に なった陰極表面加らのこのような熱電子放出で電流の連 続性を得ている。アークの熱陰極では通常 $10^{6} \sim 10^{8} \mathrm{~A} /$ $\mathrm{m}^{2}$ の陰極露流密度が必要と考えられているが，乙の電 流密度の殆どを熱電子放出でまかなうとすれば，どのよ うな物質においてそれが可能となるだるうか？

Fig. 1 は，乙机を相補的侸䚴する図である。熱陰極 加ら放出される電子放出電流は Richardson-Dashman の式で与えられ次のように表わされる。

$$
J=A T^{2} \exp \left(\frac{-e \Phi}{k T}\right)
$$

ただし， $A$ : 定数, $k:$ Boltzman 定数,

$J:$ 放出電流密度, $e:$ 電子霆荷

$T:$ 溫度, $\Phi:$ 仕事関数.

仕事関数一温度面上で, この電流密度をそれぞれ $10^{6}$, $10^{7}, 10^{8} \mathrm{~A} / \mathrm{m}^{2}$ とする三本の曲線を描き，その上に種々 の物質の沸点と仕事関数を重的ると Fig. 1 亿なる。例え ば, $\mathrm{Cu}$ では，陰極電流密度 $10^{8} \mathrm{~A} / \mathrm{m}^{2}$ を得るためには 沸点以上の陰極動作温度が必要とされるので, 熱陰極に はなり得ないととが推定される。一方，タングステンの ような高沸点材料でさえ必要な陰極放出電子流密度を得 るためには融点近傍あるいはそれ以上の温度が必要とさ れることもわかる.また，仕事関数の低い物質ほど，必 要とされる陰極動作温度が低いととが示されている。

アーク放電の環境は必ずしも真空管のなかのように清
Table 1 Tungsten-oxide electrode produced

\begin{tabular}{|c|c|c|c|}
\hline \multicolumn{4}{|c|}{ Electrode material and oxide content } \\
\hline Pure - W & & (Ternary) & \\
\hline (Binary) & & $\mathrm{La}_{2} \mathrm{O}_{3}-\mathrm{Y}_{2} \mathrm{O}_{3}-\mathrm{W}$ & $1-1(\%)$ \\
\hline $\mathrm{ThO}_{2}-\mathrm{W}$ & $2(\%)$ & $\mathrm{La}_{2} \mathrm{O}_{3}-\mathrm{Y}_{2} \mathrm{O}_{3}-\mathrm{W}$ & $1.5-0.5$ \\
\hline $\mathrm{MgO}^{-}-\mathrm{W}$ & 2 & $\mathrm{La}_{2} \mathrm{O}_{3}-\mathrm{Y}_{2} \mathrm{O}_{3}-\mathrm{W}$ & $0.5-1.5$ \\
\hline Zro - W & 2 & $\mathrm{La}_{2} \mathrm{O}_{3}-\mathrm{CeO}_{2}-\mathrm{W}$ & $1-1$ \\
\hline $\mathrm{ThO}_{2}-\mathrm{W}$ & 2 & $\mathrm{r}_{2} \mathrm{O}_{3}-\mathrm{CeO}_{2}-w$ & $1-1$ \\
\hline $\mathrm{La}_{2} \mathrm{O}_{3}-\mathrm{W}$ & 1,2 & $\mathrm{r}_{2} \mathrm{O}_{3}-\mathrm{CeO}_{2}-W$ & $1.5-0.5$ \\
\hline$Y_{2} 0_{3}-W$ & 2,3 & $\mathrm{Y}_{2} \mathrm{O}_{3}-\mathrm{CeO}_{2}-W$ & $0.5-1.5$ \\
\hline $\mathrm{CeO}_{2}-\mathrm{W}$ & 2 & & \\
\hline
\end{tabular}

净ではない，とくに溶接の場合作動ガスは通常アルゴン やへリウムのような不活性ガスが用いられるが，しばし ば，大気の巻き込みが生じ電極は酸化性のガスにさらさ 机ることになる。しかあ，アーク放電の陰極はプラズマ イオンの衝撃をうける。

トリア入りタングステンは，いわば，タングステン粉 末にトリウムの酸化物粉末を混入し作成したものであ る. その機構は必ずしあ明らかではないむのの，アーク 故電の陰極としてイオンの衝撃にさらされるような状況 の下で実効的な仕事関数が低くその電子放出は絉タング ステンに比較して極めて安定している。

以上のような状況を考虑すれば，動作中に溶融変形を 起こさない，電子放出能力の優れたしかも安定した性能 を保持できる電極を構成するには，基本的にタングステ ンのような高沸点金属をあちい，それに，仕事関数の低 く，しかも，酸化されることによって，その性質を大き くは変化させない物質を添加して, 実效的な仕事関数の 低下が期街されるようにする方法が最も有效な方法であ ると考えられる、以上のような考察の下に試作した各種 タングステン電極を Table 1 亿示す. 電極径は1.6, 2.4, および, $3.2 \mathrm{~mm}$ の三種で先端形状は主として 45 度に研 磨して用いている。

\section{3. 特性比較実験}

アーク放電の電極 (陰極) として要求される性能は主 として次のようなあのであろう.

1）点弧容易にして確実なとと．陰棈点の這い上がり 現象などを生じないとと。

2）動作中の溶融変形や消耗などによるアーク特性の 変化を生じないとと。

3）アークの安定性や制御性に優れていること.

4）取り扱いの容易なとと.

以上の諸条件にたいする検討，および，生じるアーク の特性についての各種タングステン電極での比較实験を 行なった。

\section{1 電流電圧特性}

测定されたアークの電流一霞圧特性の例を Fig. 2 に示 す。陽極は水冷銅板である。

容易に予想されるように純タングステン $(\mathrm{P}-\mathrm{W})$ 電極 之酸化物入りタングステン電極では明らかに異なってい る. P-W 電極は, 低電流域で他の電極と比べ非常に高 い電旺を有する。一方，他の二元系の酸化物入りタング

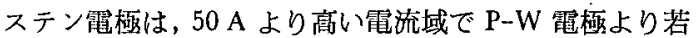
干低い值を示し，正抵抗特性を示している。 また，三元 

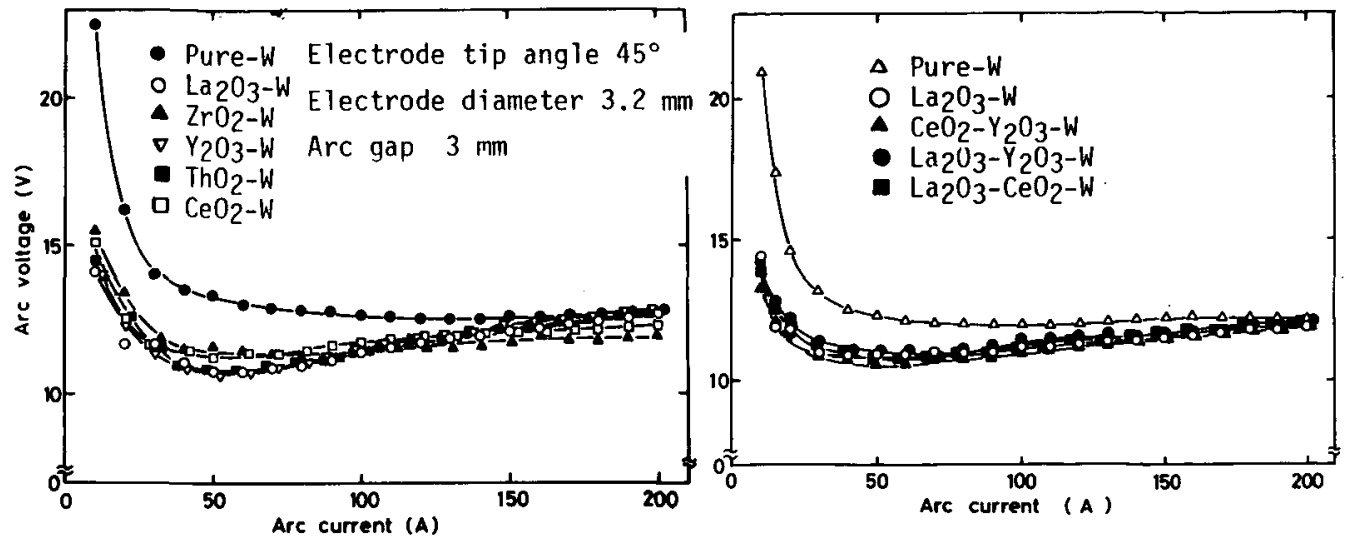

Fig. 2 Voltage-current characteristics

系電極は，二元系電極之同㥞の傾向を示している，との 測定結果はよく知られているように酸化物入りタングス テン電極先端部の溶融変形が $\mathrm{P}-\mathrm{W}$ 電極に比較してすく ないととを示している4).

ジルコニア入りタングステン $\left(\mathrm{ZrO}_{2}-\mathrm{W}\right)$ や $\mathrm{P}-\mathrm{W}$ で は，測定中の電極の溶融変形が著しく誤差が大きくな る。

\section{2 アーク起動性}

点弧の容易さを評価する方法として，乙てでは高周波 点弧による点弧可能な最小の開路電圧 (Open Circuit Voltage，O.C.V., 無負荷電圧) の比較を行なった。

広く一般に使用されている高周波点弧回路の一部を変 更して, 開路電圧を変化させ，10秒間の高周 波印加中 に，アークの持続放電に移行するか否かを観察した.

タングステン陰極，水冷銅陽極間汇あらかじめ設定す 万開路電圧を $18 ， 22 ， 24 ， 36 \mathrm{~V}$ と㽜化させ，それぞれの 設定值でそれぞれ30回の点弧を武み，通常の持続アーク 放電に移行したものを Self-sustaining arc，アークに移 行してあ陰極点の這い上がりが生じたり，消弧したりす るものを Non self-sustaining arc, 全くアーク放電に移 行しないあのを Failure, としてヒストグラムにしたも のを Fig. 3 に示す.

てれによると， $\mathrm{P}-\mathrm{W}$ と $\mathrm{MgO}(2 \%)-\mathrm{W}$ のアーク起 動性が明らか江少っている。元ば, O.C.V.が $36 \mathrm{~V}$ の時, これら二種の電極ではほとんど正常なアークに移 行していないのに対し，それ以外の電極では逆にほとん ど正常なアークに移行している。一方, 二元系電極の中 で最も優れたアーク起動性を持っている電極が $\mathrm{La}_{2} \mathrm{O}_{3}$ ( $2 \%)-W$ である. O.C.V. が $22 \mathrm{~V}, 24 \mathrm{~V}$ の場合のアー ク起動回数を $\mathrm{ThO}_{2}(2 \%)-\mathrm{W}, \mathrm{Y}_{2} \mathrm{O}_{3}(2 \%)-\mathrm{W}$ などと 比べると, $\mathrm{La}_{2} \mathrm{O}_{3}(2 \%)-\mathrm{W}$ は，安定なアークに移行し た割合が多いととがわかる．さらに，三元系電極に注目 してみると，若干の差はあるもののアーク起動回数は， $\mathrm{La}_{2} \mathrm{O}_{3}(2 \%)-\mathrm{W}$ とほぼ同程度であるとみなすととがで きる.

O.C.V.Kよるアーク起動性では必ずしす起動しやす さの評価として十分ではないと考えられる。そてで，1 秒間の点弧，15秒間の休止というサイクルを 100 回連続 して繰り返し，高周波のスイッチオン後正常アーク放電 に移行する迄の時間の測定を行ないその分布を検討し た.との测定では，市眅のインバータ TIG 電源を用い

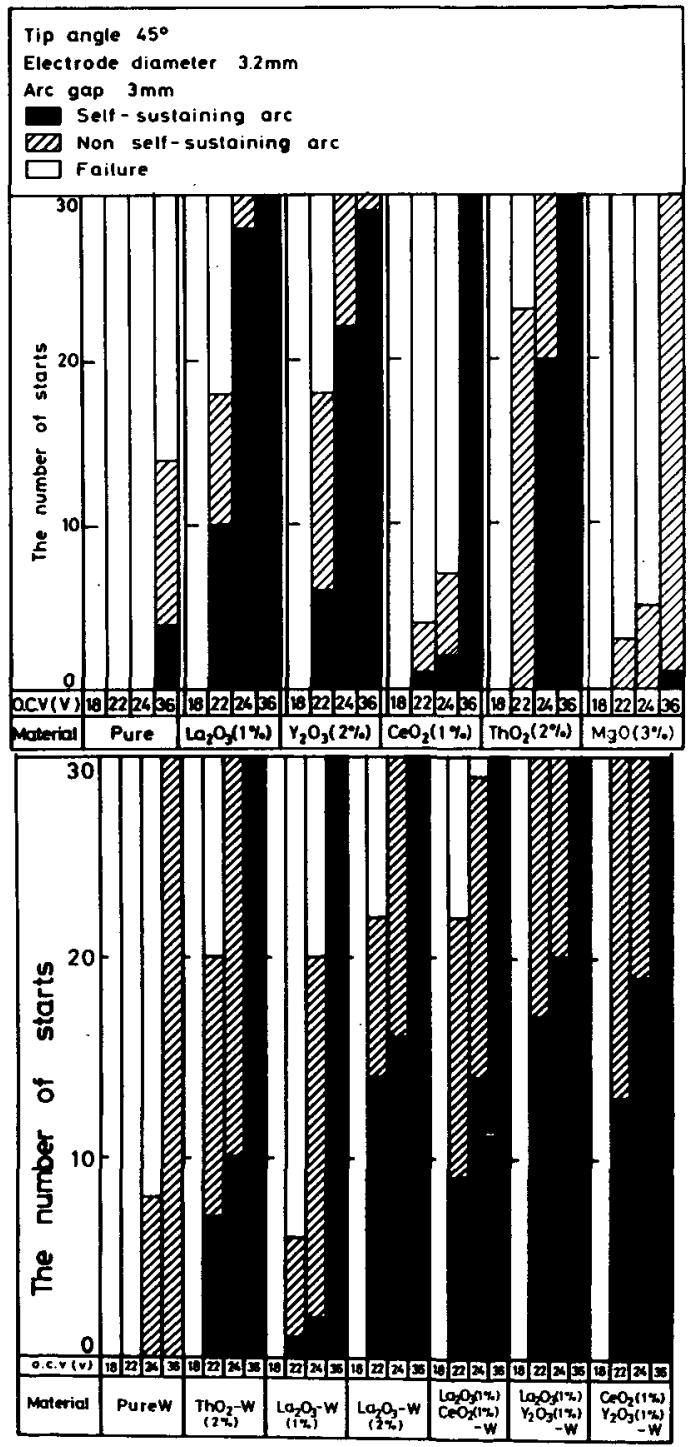

Fig. 3 Arc starting characteristics evaluated by $u$. C.V. test 


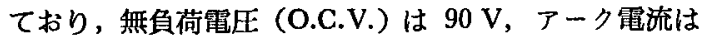
30 A に設定し，1秒経過してもなお正常アークに移行 しない場合は NGとして処理してある. Fig. 4 にその結 果を示すが, $\mathrm{La}_{2} \mathrm{O}_{3}-\mathrm{Y}_{2} \mathrm{O}_{3}-\mathrm{W}$ 系がやや良好な特性をし めしている。しかし，多数回起動によあなうアーク起動 性の少化は全ての電極で多少とす生じており，それらは NG の回数に表われている.

\section{3 アーク压力}

各電極について，先端角を45度に研磨し，半導体压力 变換器を $1 \mathrm{~mm} \phi$ の小孔を有する水冷銅陽極に取りつ け，陽極側のアーク王力を測定した結果を Fig. 5 亿示 す.

いずれす，ほばガウス分布に近い曲線を示すが，P-W， $\mathrm{ZrO}_{2}-\mathrm{W}$ が全体的に低い压力を示す。また, $\mathrm{Y}_{2} \mathrm{O}_{3}$ ( $3 \%)-W \mathrm{CeO}_{2}(1 \%)-\mathrm{W}, \mathrm{La}_{2} \mathrm{O}_{3}(2 \%)-\mathrm{W}$ は, ほほ 同程度のアーク正力を示しているが， $\mathrm{ThO}_{2}(2 \%)-\mathrm{W}$ は，それらよりやや低い值を示している，さらに，三元 系電極のアーク在力は, $\mathrm{La}_{2} \mathrm{O}_{3}(2 \%)-\mathrm{W}$ のあの之ほほ 同程度である。

Fig. 6 亿電極先端形状とアーク圧力の関係を示す．先 端を少し切り落としただけで，アーク圧力が非常に減少 することがわかる.たとえば，先端の flat な部分を，1

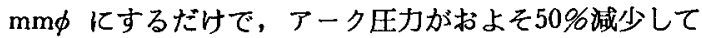
いる. したがって，Fig. 5 で P-W 電極での压力が低く なるのは, 電極先端部の溶虽変形によって先端形状が平

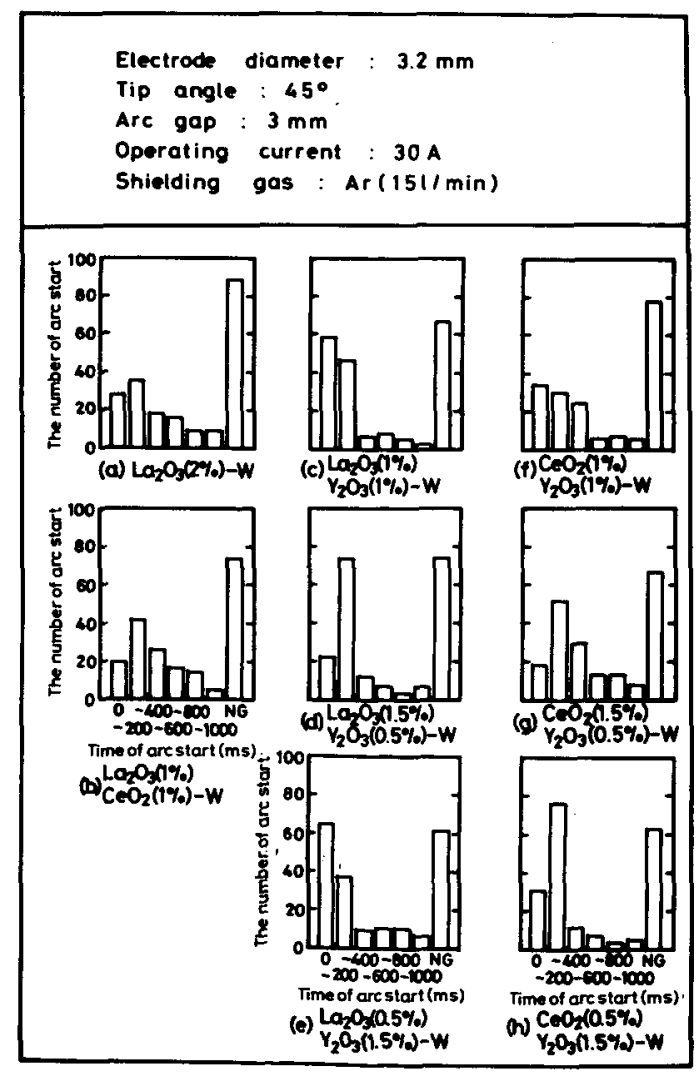

Fig. 4 Arc starting characteristics evaluated by repetitive arc starting test
坦に近ついたことが主要因であると考えられる。

Fig. 7 に，アーク王力の電流依存性を示す。さきに， Fig. 5 で示した $\mathrm{Y}_{2} \mathrm{O}_{3}-\mathrm{W}, \mathrm{CeO}_{2}-\mathrm{W}, \mathrm{La}_{2} \mathrm{O}_{3}-\mathrm{W}$ および 三元系電極と $\mathrm{ThO}_{2}-\mathrm{W}$ のアーク压力の差異は, 電流值 が 150 A 以上ではっきりと認められ, 電流值の增加と共 に差が広がっている。 さらに，P-W 電極は，75A あた りからすでに酸化物入り篋極よりも低い值を示し，300 $\mathrm{A}$ では $\mathrm{La}_{2} \mathrm{O}_{3}-\mathrm{W}$ などの電極に比べておよそ半分の区 力値となっている.

\section{4 電極溶断現象}

アーク電流を非常に大きくするとタングステン電極は 陰極部と冷却部（コレットと接する部分）との中間で溶 断する。これは陰極部では電子放出のために冷却効果が あり，したがって，両端に冷却部を有する，ジュール加 熱されているタングステン棒とおなじ状況が生じるため であると考えられる。したがってとの溶断電流住電極の 電気伝導度と融点に最す強く依存するとかんがえられ， 電極の最大許容電流值を決定する. $1.6 \mathrm{~mm} \phi$ の電枯 $の$ 溶断電测值の測定結果を Table 2 亿示す，結果は，

190〜200A であり，ほとんど差異がない，てれは，てれ らの電極の高温抵抗に殁よ゙差異がないためであると思わ れる。

\section{5 アーク放電と電極先端部の変化}

電極径 $1.6 \mathrm{~mm}$ を用いて $180 \mathrm{~A} ， 1$ 時間の放電を行 なった後の電極先端の形状の一例を Fig. 8 に示す. との
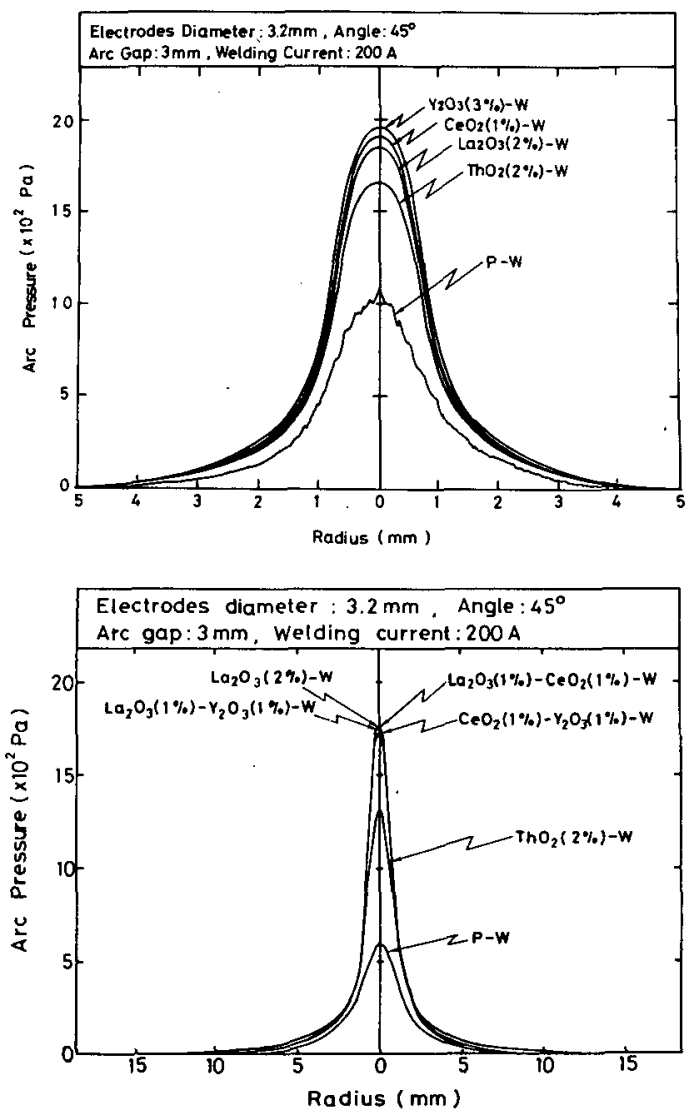

Fig. 5 Arc pressure distribution measured at anode 
電極径での溶断電流は約 $200 \mathrm{~A}$ であり, 採用した条件は かなり苛酷な条件に相当する。 また, Fig. 9 には同様に 電極内部の組織変化の一例を示す.

結果は, $\mathrm{La}_{2} \mathrm{O}_{3}(2 \%)-\mathrm{W}, \mathrm{Y}_{2} \mathrm{O}_{3}(2 \%)-\mathrm{W}, \mathrm{CeO}_{2}$ (1\%)-W などに殆ど形状の変化が見られないのに対 L, $\mathrm{ThO}_{2}(2 \%)-\mathrm{W}, \mathrm{ZrO}_{2}(2 \%)-\mathrm{W}, \operatorname{MgO}(2 \%)-\mathrm{W}$ では先端部の溶融変形や内部の気孔の発生がみられる. また, 三元系電極は, 先端部の形状の変化もほとんどな く $\mathrm{La}_{2} \mathrm{O}_{3}(2 \%)-\mathrm{W}$ などと同様の形状を保っていた.

電極の動作温度の差を推定するために，熱電対によっ

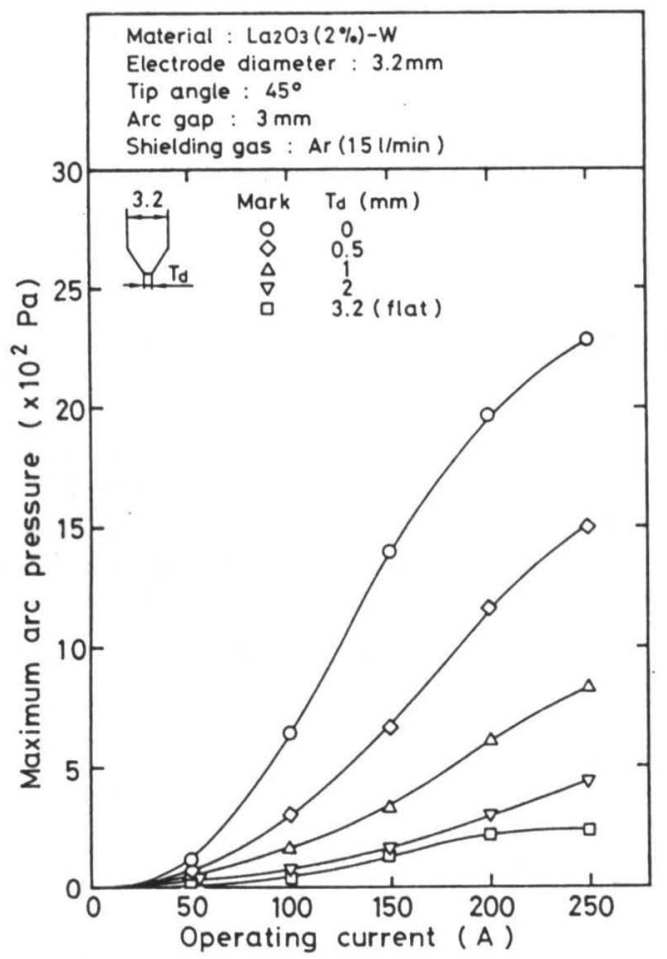

Fig. 6 Effect of truncated diameter of electrode on maximum pressure in argon gas
Table 2 Current carrying capacity in appropriate extension

\begin{tabular}{|c|c|}
\hline Electrode material & Current maximum \\
\hline Pure - W & $200 \mathrm{~A}$ \\
$\mathrm{ThO}_{2}(2 \%)-\mathrm{W}$ & $195 \mathrm{~A}$ \\
$\mathrm{La}_{2} \mathrm{O}_{3}(1 \%)-\mathrm{W}$ & $200 \mathrm{~A}$ \\
$\mathrm{La}_{2} \mathrm{O}_{3}(2 \%)-\mathrm{W}$ & $205 \mathrm{~A}$ \\
$\mathrm{Y}_{2} \mathrm{O}_{3}(3 \%)-W$ & $190-195 \mathrm{~A}$ \\
$\mathrm{CeO}_{2}(1 \%)-\mathrm{W}$ & $200 \mathrm{~A}$ \\
$\mathrm{Ce} \mathrm{O}_{2}(2 \%)-\mathrm{W}$ & $200 \mathrm{~A}$ \\
\hline
\end{tabular}

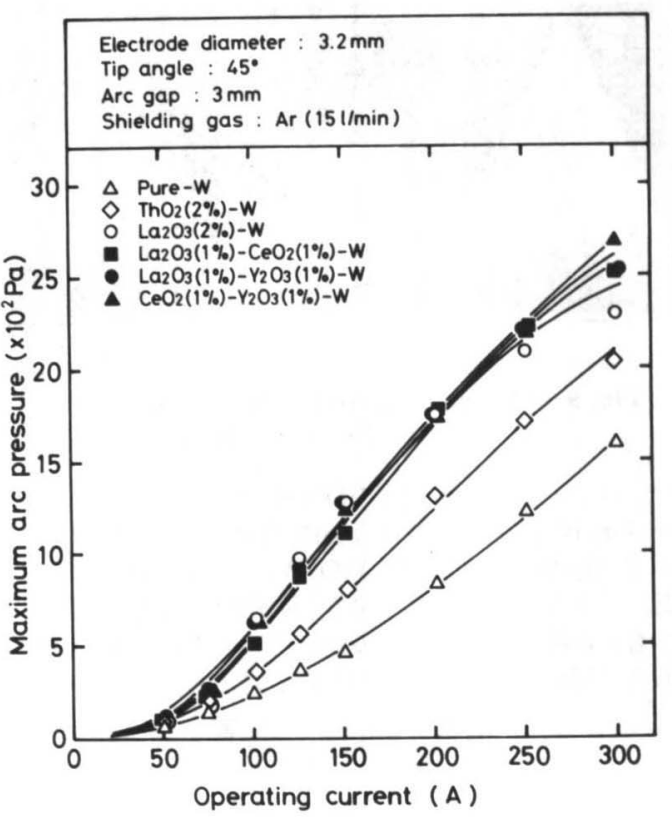

Fig. 7 Relationship between maximum arc pressure and arc current for various electrode

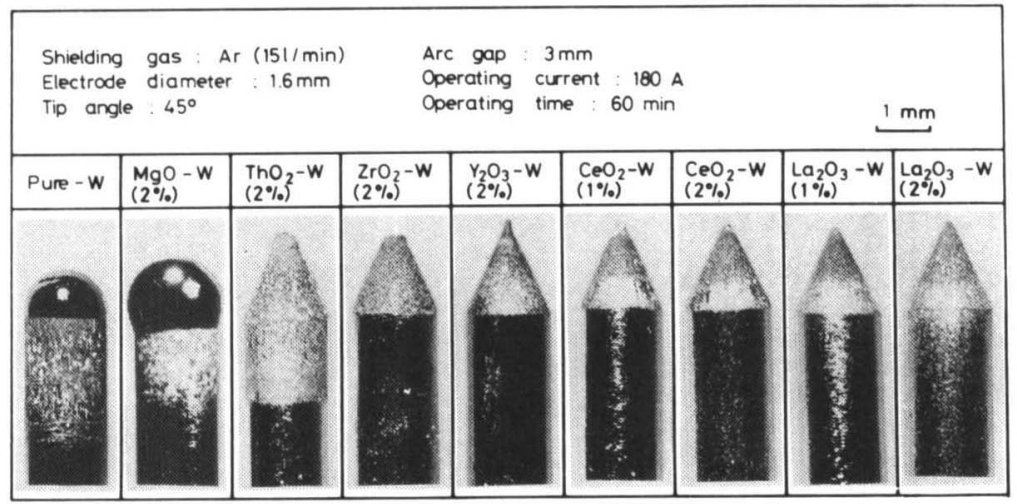

Fig. 8 Appearance of electrode shape after long term operation with high current density 


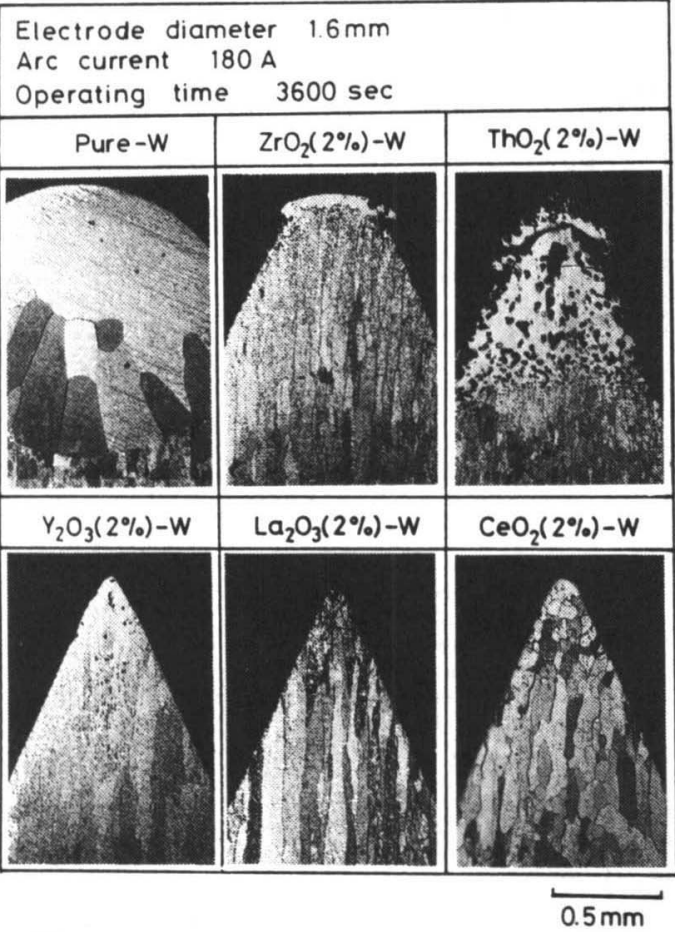

Fig. 9 Change in microstructure of cross-section of electrode after heavy loading

て陰極の近傍の電極温度の測定をおこなった。その結果 を Fig. 10 に示す. あきらかに $\mathrm{ThO}_{2}-\mathrm{W}$ に比較して他 の $\mathrm{CeO}_{2}-\mathrm{W}, \mathrm{La}_{2} \mathrm{O}_{3}-\mathrm{W}, \mathrm{Y}_{2} \mathrm{O}_{3}-\mathrm{W}$ などの電極の温度が 低いことがわかる. 陰極動作部の温度も同様の傾向を示 すむのと推定される. この動作温度の差は電極の溶融変 形の差異に強い関連をむつものと考えられる。

\section{4. 結言}

酸化物入りタングステン電極を溶接アークに適用する ために純タングステン $(\mathrm{P}-\mathrm{W})$ ，および数種の酸化物入 りタングステン電極 $\left(\mathrm{MgO}-\mathrm{W}, \mathrm{ZrO}_{2}-\mathrm{W}, \mathrm{ThO}_{2}-\mathrm{W}\right.$, $\mathrm{CeO}_{2}-\mathrm{W}, \quad \mathrm{Y}_{2} \mathrm{O}_{3}-\mathrm{W}, \quad \mathrm{La}_{2} \mathrm{O}_{3}-\mathrm{W}$, 各 $2 \%$, および, $\mathrm{La}_{2} \mathrm{O}_{3}, \mathrm{Y}_{2} \mathrm{O}_{3}, \mathrm{CeO}_{2}$ それぞれの 2 種-各 $1 \%$-ずつの

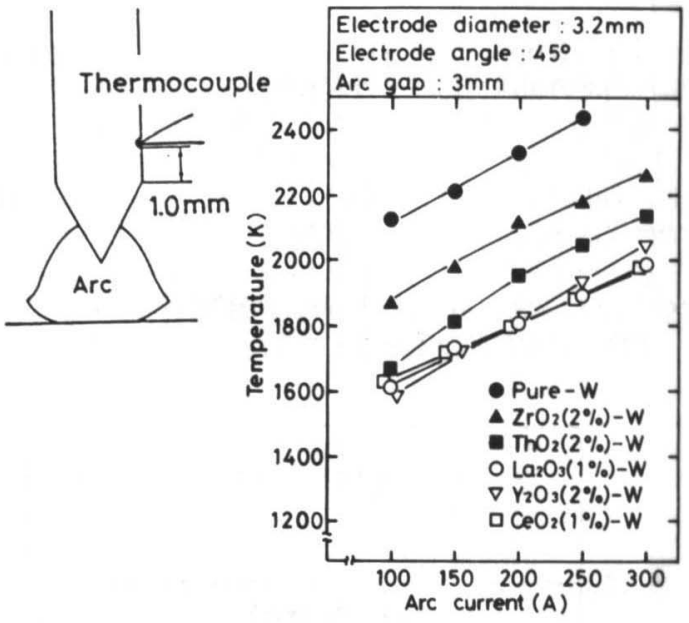

Fig. 10 Electrode temperature measurement by thermocouple

酸化物添加の三元系 W) を試作し, その点弧し易さ, 電 流電圧特性, アーク圧力, 電極温度, 動作中の形状変化 と組織変化などを比較して調べ, その結果 $\mathrm{La}_{2} \mathrm{O}_{3}\left(290^{\circ}\right)-$ $\mathrm{W}, \mathrm{Y}_{2} \mathrm{O}_{3}(2 \%)-\mathrm{W}, \mathrm{CeO}_{2}(2 \%)-\mathrm{W}$, 三元系 $\mathrm{W}$ の各 電極が他の $\mathrm{P}-\mathrm{W}, \mathrm{MgO}-\mathrm{W}, \mathrm{ZrO}_{2}-\mathrm{W}, \mathrm{ThO}_{2}-\mathrm{W}$ 等の 各電極よりもかなり優れた性能を有することを明らかに した.さらに，これらの優れた特性に陰極部の動作温度 の低いととが強い関連性を有することを示唆した。

\section{引用 文 献}

1）星合正治，島村道彦，“電子とその作用 (電子工学講座)”、オ一 么社 (1961).

2) Chapin, N. A., Cobine, J. D. and Gallagher, C. J., "Tungsten-Thoria Electrod for Inert Arc Welding", Welding Journal 30, 529 (1951).

3) Winsor, L.P. and Turk, R. R, "A Comparative Study of Thoriated Zirconiated and Pure Tungs ten Electrodes". Welding , ournal 36, $113 \mathrm{~s}$ (1957)

4) Flemming, D, "Eigenschaften von Wolframelekt roden zum WIG-Schwei en", Schwei en und Schnei den 18, 220 (1966).

5）西川淳；TIG 溶接用タングステン電極のアーク特性に関する研 究, 大阪大学工学博士学位請求論文 (1969) 